Int. J. Speleol. 20 (1991): 15-22

\title{
Metabolic efficiency and regulation of body weight: a comparison between life in hypogean and epigean ecosystems
}

\author{
Jayant Biswas *
}

\begin{abstract}
SUMMARY
In the present study metabolic efficiency in the epigean and hypogean populations of Nemacheilus evezardi (Day) was examined. Different experiments were conducted, in both populations, by keeping them either in restricted oxygen or restricted feeding conditions, including starvation. Results clearly show that the rate of oxygen consumption for the hypogean population was significantly less as compared to its epigean counterpart. Further, results also suggest that the hypogean population has a tremendous capacity to maintain its metabolic activity and regulate its body weight under severe conditions characterized by an absence or a limited supply of food.
\end{abstract}

\section{INTRODUCTION}

Kotumsar cave, an ideal and simplified subterranean cave is situated at the bank of the river Kanger in Kanger valley National

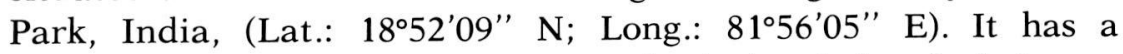
remarkable constancy in various geophysical and chemical characteristics, (Biswas, 1990). Several true cavernicoles have been reported from this cave (Sinha and Agarwal, 1977; Biswas, 1990; Biswas et al., $1990 \mathrm{a}, \mathrm{b})$.

The subterranean organisms are usually familiar with the situations characterized by decreased and erratic food supply. The reduction in respiratory intensity and a general decrease in activity pattern in many cavernicoles reflect their physiological adaptation in food-limited environment. This phenomenon is often referred as metabolic economy (Poulson, 1963; 1964). India.

* Department of Bioscience, Ravishankar University, Raipur, 492010 (M.P.), 
In the present study the epigean and hypogean populations of Nemacheilus evezardi (Day) were used. The former inhabits in the Kanger river system, whereas the latter has successfully colonized the Kotumsar cave. It has already been established that the hypogean population exhibit several morphological, behavioural and physiological divergence (Biswas, 1990; Biswas et al., 1990a, b, c; Biswas and Pati, 1991). The object of the present investigation is to compare the metabolic efficiency between the epigean and hypogean populations.

\section{MATERIALS AND METHODS}

Live specimens of Nemacheilus evezardi belonging to epigean and hypogean populations were collected from their natural habitat. The former inhabits fast flowing hill streams and the latter is a cave dweller. All fishes were brought to the laboratory and allow to adapt separately in two identical aquaria $(75 \times 30 \times 30 \mathrm{~cm})$. The cave fishes were transported in a light tight container and kept inside a dark room throughout the course of the study. A dim red light was used inside the dark room in order to perform different manipulations on the fish. The water temperature varied between $26 \pm 1^{\circ} \mathrm{C}$ during all experiments. The stock aquarium containing the river fish was kept in the animal quarter, in natural daylenght conditions and in the ambient temperature at Raipur (Lat.: $21^{\circ} 14^{\prime} \mathrm{N}$; Long.: $81^{\circ} 38^{\prime}$ E).

The fish chosen for different experiments were approximately of the same snout to vent lenght i.e.. $4.0 \pm 0,5 \mathrm{~cm}$. Their body weight was $585 \pm 10 \mathrm{mg}(\mathrm{n}=20$; 10 each).

Experiment-1. Oxygen consumption by muscle tissue.

Four individuals, each from hypogean and epigean populations, were randomly chosen and starved for a period of one week. On seventh day, the muscle tissue was isolated carefully from each individual and rate of oxygen consumption $\left(\mu \mathrm{l} \mathrm{O}_{2} / \mathrm{g} / \mathrm{h}\right)$ was monitored with the help of an oxygen electrode. 
Experiment-2. Feeding diets and body weight.

Sixteen cave or river fish were chosen from the stock aquaria and randomly divided into four groups (Groups - A-D) of four each. Each fish were maintained individually in a separate one liter jar. Prior to each experiment each individual was weighed. Fishes of group 'A' were fed with minced liver ad libitum. Fishes of group 'B' and ' $C$ ' were fed daily with $3 \mathrm{mg} / \mathrm{g}$ and $1 \mathrm{mg} / \mathrm{g}$ body weight, respectively. The fishes of group ' $\mathrm{D}$ ' were starved throughout. The water was changed every fourth day. On day 31 each fish was reweighed and the changes in body weight was compared. An arc-sine transformation was made on each datum. Data were analyzed by analysis of variance (ANOVA) and Duncan's multiplerange test (Bruning and Kintz, 1977; Duncan, 1955).

\section{RESULTS}

Results are summarized in figures 1-3.

Oxygen consumption of muscle tissue: the rate of oxygen consumption by muscle tissue of epigean fish was higher as compared to its hypogean counterpart (Fig. 1; $\mathrm{P}<0.05$ ). Furthermore, hypogean fish survived longer than the epigean fish in an oxygen limited environment (Fig. 2; $\mathrm{P}<0.001$ ).

Feeding diets and body weight: the results of ANOVA show a statistically significant species effect as well as a diet effect. However, the interaction effect was not statistically significant which shows that both factors are independent (Fig. 3). Body weight of either epigean or hypogean fish declined following starvation as well as restricte feeding. However, the magnitude of decrement was more marked in the epigean fish than in its hypogean counterpart $(\mathrm{P}<0.01)$.

\section{DISCUSSION}

Several direct or indirect techniques have been used to study the metabolism in varieties of cavernicoles (see reviews: Poulson, 1964; Vandel, 1965; Barr, 1968; Culver, 1982; Hüppop, 1985). The first systematic account on the cave adaptive features including the measurement of metabolic rates was published by Poulson (1963), 
on a series of hypogean Amblyopsid fish of different phylogenetic age. He observed a maximum metabolic rate in the epigean Chologaster agassizi over the troglobitic Typhlichtys subterranea and Ampblyopsis spelaea to the most cave-adapted species Amblyopsis rosae. Furthermore, Ercolini et al. (1987) drew identical conclusion in comparing the rate of oxygen consumption among a troglobite

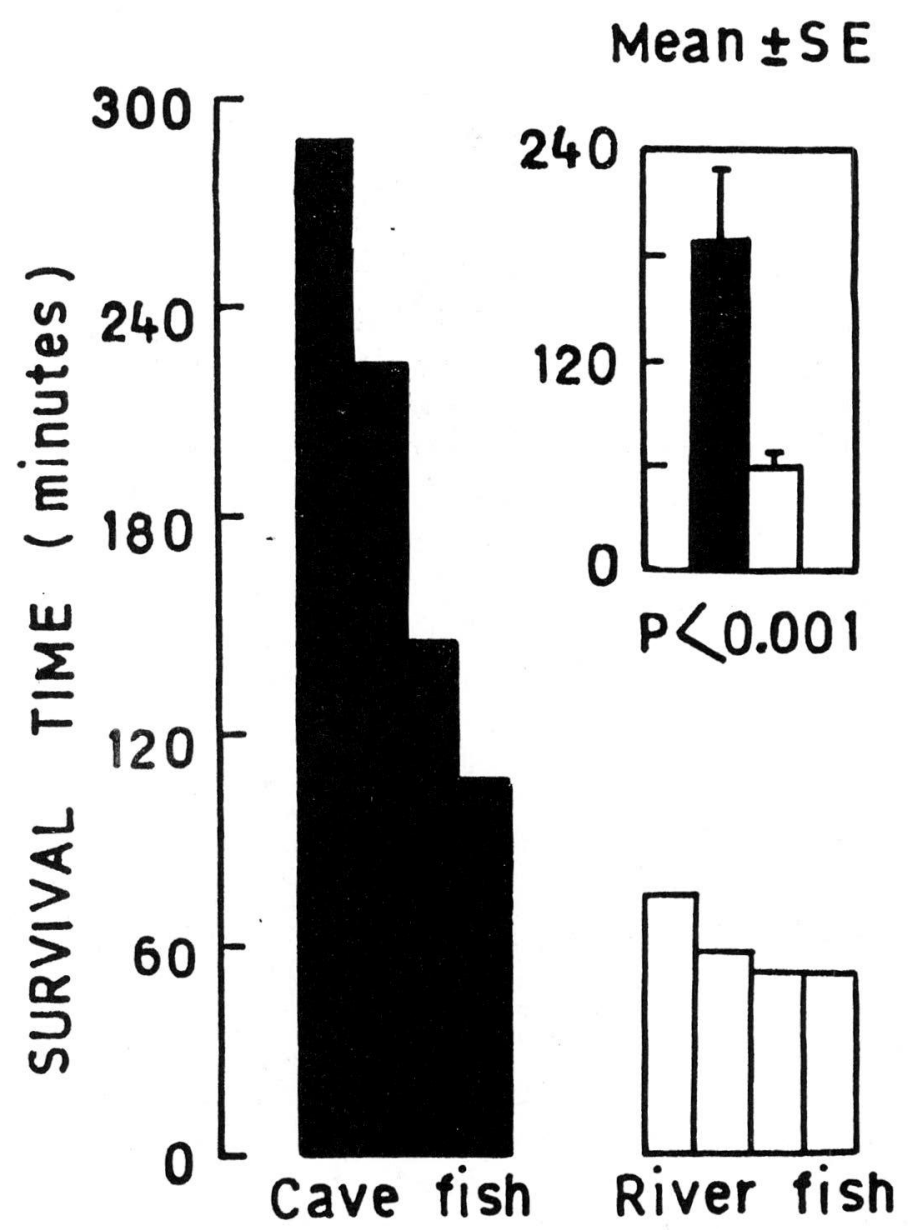

Fig. 1 - Histograms illustrating rate of oxygen consumption by muscle tissue of cave (hypogean) fish \& river (epigean) fish. Inset showing the mean $\pm 1 \mathrm{SE}$ of cave and river fish which differs significantly from each other ( $P$ from $t$-test $<0.05$ ). 


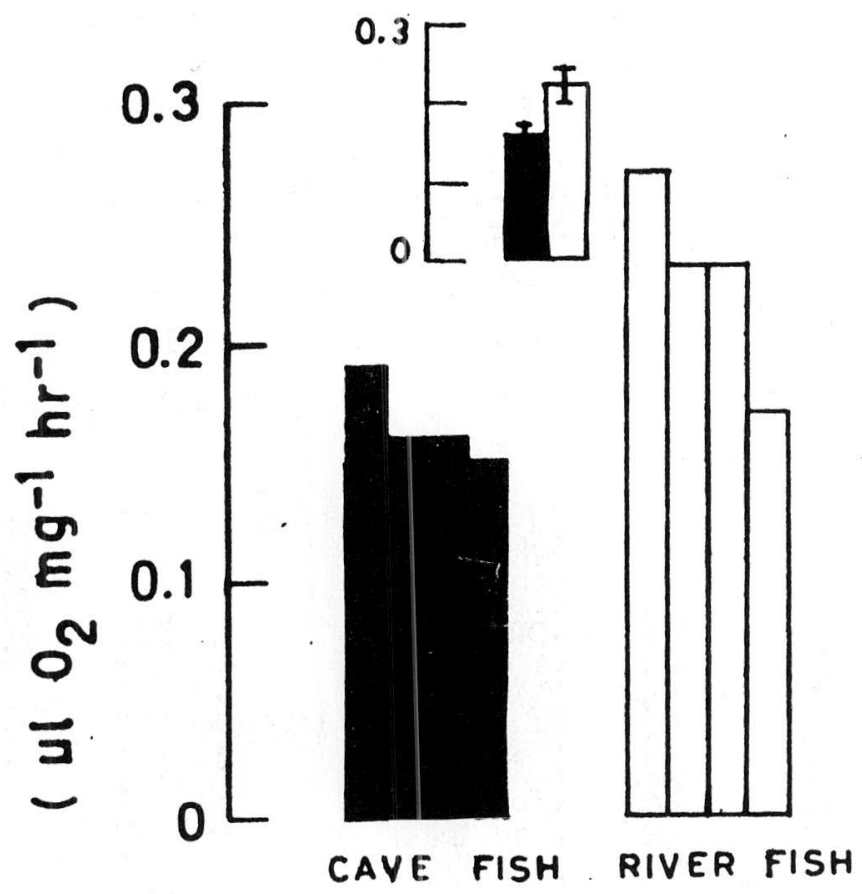

Fig. 2 - Histograms representing survival time of either cave or river fish in a closed bottle. Right inset showing the mean $\pm 1 \mathrm{SE}$ of cave and river fish wich differs significantly (P from t-test $<0.001$ ).

(Barbopsis devecchii), a troglophile (Phreatichtys andruzzii) and their closest epigean ancestor (Puntius lateristriga).

As is known, different biological activities may modify the metabolic rate of a living organism, the influence of metabolism modifying factors can be eliminated when the oxygen consumption of a tissue can be monitored in vitro (Dickson and Franz, 1980; Biswas, 1990; Biswas and Pati, 1991). In the present study the respiring rate of muscle tissue of starved epigean or hypogean fish was measured in vitro and results evidence a lower metabolic rate in the hypogean fish. Further, a period of only one week starvation imposed a marked change in muscle tissue respiration, in the epigean population only, as compared to its oxydative metabolism in full feeding condition, its values being $0.427 \pm 0.1 \mu \mathrm{lO} / \mathrm{g} / \mathrm{h}$ 


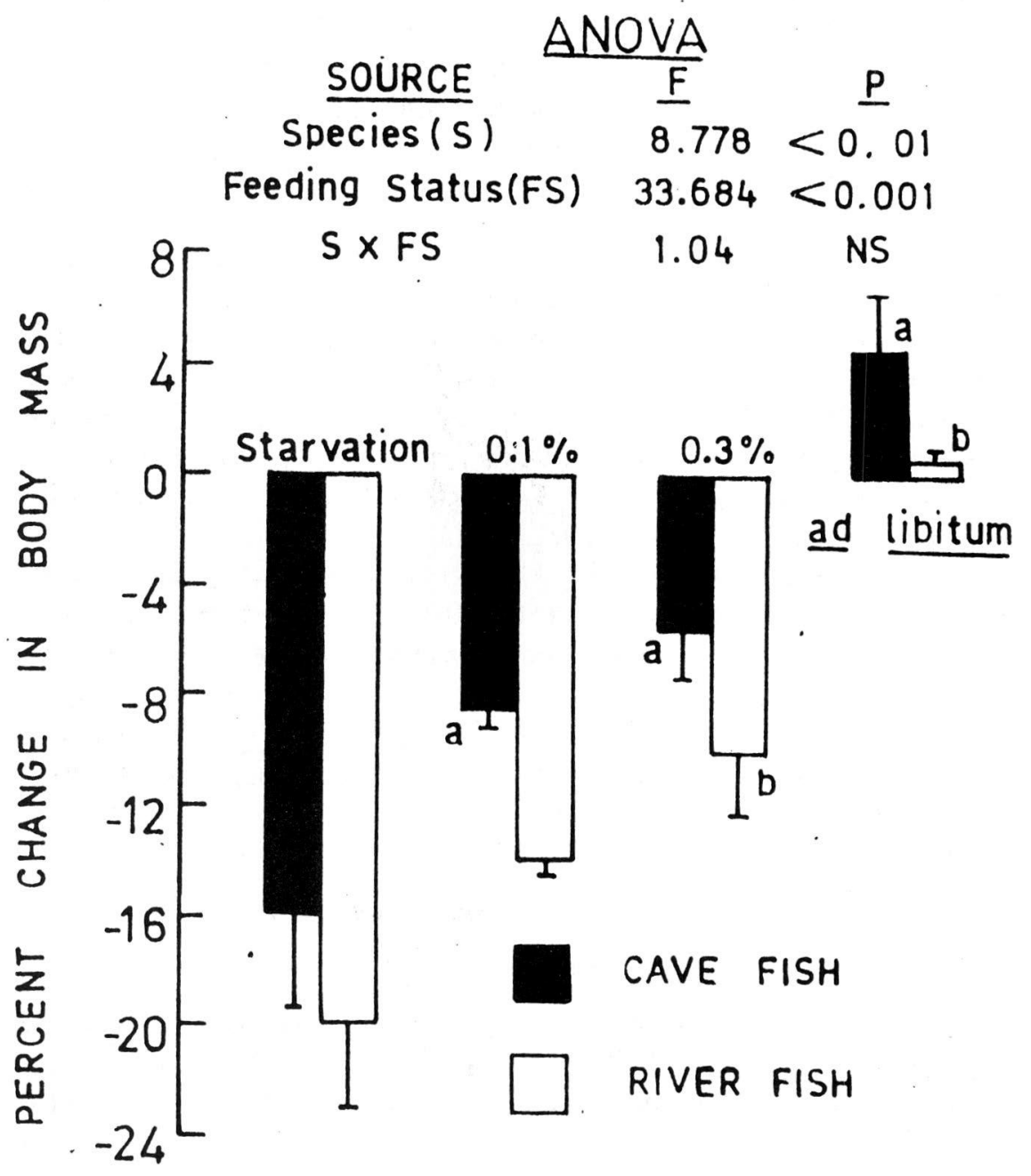

Fig. 3 - Histograms illustrating percent change in body mass of either cave or river fish following starvation or restricted feeding. The percent change in body mass was computed relative to the initial body weight of an individual fish. (a) Differs from the mean value of starved cave fish. (b) Differs from the mean value of starved river fish. 
(Biswas and Pati, 1991). These results could be favourably compared with those published earlier (Jeannel, 1929; Burbanck et al., 1948; Dresco-Derouet, 1959). It has been already demonstrated that the fishes belonging to the cave population exhibit an air-gulping behaviour which is completely absent in their epigean counterparts (Biswas et al., 1990a). Upon denied access to atmospheric oxygen, hypogean fish survived 132 minutes longer than its epigean relatives (Fig. 2). Although the method employed was relatively crude, it supports the above findings.

In another experiment, it was found that the reduction in body weight was always greater in epigean fish, irrespective of the feeding diets. Under an ad libitum feeding schedule, the hypogean fish gained more weight as compared to its epigean relatives. Hüppop (1986) reported, that during a starvation period of 29 days the body mass loss in the hypogean Astyanax mexicanus (alias Anoptichthys $s p$.) was only $9.5 \%$, whereas a $16.5 \%$ bulk loss was recorded in its epigean counterpart Astyanax fasciatus.

When food was supplied only at the rate of $1 \mathrm{mg} / \mathrm{g}$ body weight, hypogean fish lost less weight as compared to epigean fish. It is thus clear that $1 \mathrm{mg} / \mathrm{g}$ body weight diet was as worse as starvation for the epigean fish only. The cave fish with same food regimen $(1 \mathrm{mg} / \mathrm{g})$ shows statistically significant change from its respective starved group. Further, the food regimen $(3 \mathrm{mg} / \mathrm{g})$ shows same effect for both the populations (Fig. 3). This suggests that in a food limited environment hypogean Nemacheilus evezardi has developed some mechanism(s) to reduce energy expenditure.

\section{ACKNOWLEDGEMENTS}

I am very much indebted to Dr. A. K. Pati, Department of Bioscience, Ravishankar University, Raipur (India) who kindly edited part of this manuscritp. I am also thankful to Dr. B. B. Pd. Gupta, School of Life-Sciences, NEHU, Shillong (India), who provided facility for measuring tissue $\mathrm{O}_{2}$ consumption by oxygen electrodes.

\section{REFERENCES}

BARR, T.C., Jr. 1968. Cave ecology and the evolution of troglobites, pp. 35-102. In T. Dobzhansky, M. K. Hecth W.C. Steere (eds.), Evolutionary Biology II Plenum Press, New-York.

BISWAS, J. 1990. Biospeleology: behavioural and physiologic adaptations in a cavernicole. Ph.D thesis, Ravishankar University, Raipur, India.

BISWAS, J., A.K. PATI and R.K. PRADHAN. 1990a. Circadian and circannual rhythms in air-gulping behaviour of cave fish. J. Interdisc. Cycle Res. 21: 257-268. 
BISWAS, J., A.K. PATI, R.K. PRADHAN and R.S. KANOJE. 1990b. Comparative aspects of reproductive phase dependent adjustments in behavioural rhythms in epigean and hypogean fish. Comp. Physiol. Ecol. 15: 134-139.

BISWAS, J., R.K. PRADHAN and A.K. PATI. 1990c. Studies on burying behaviour in epigean and hypogean fish: an example of behavioural divergence. Mem. Biospeleol. 17: 33-41.

BISWAS, J. and A.K. PATI. 1991. Influence of thyroid hormones on muscle tissue respiration in hypogean and epigean population of Oreonectus evezardi (Dav.). Indian J. Exp. Biology 29: 933-936.

BRUNING, J.L. and B.L. KINTZ. 1977. Computational Handbook of Statistics. Scott. Foresman. Glenview. III.

BURBANCK, W. D., J. P. EDWARDS and M.P. BURBANCK. 1948. Toleration of lowered oxygen tension by cave and stream crayfish. Ecology 29: 360-367.

CULVER, D.C. 1982. Cave life. Evolution and Ecology. Harvard University Press, Cambridge, Massachusetts and London.

DICKSON, G.W. and R. FRANZ. 1980. Respiration rates, ATP turnover and adenylate energy charge in excised gills of surface and cave cray fish. Comp. Biochem. Physiol. 65A: 375-379.

DRESCO-DEROUET, L. 1959. Contribution a l'étude de la biologie de deux crustacé aquatiques cavernicoles: Caecosphaeroma burgundum D. et Niphargus orcinus virei $\mathrm{Ch}$. Vie et Milieu 10: 321-346.

DUNCAN, D.B. 1955. Multiple range and multiple F test. Biometrics 11: 1-6.

ERCOLINI, A., R. BERTI, L. CHELAZZI and G. MESSANA. 1987. Oxygen consumption in hypogean and epigean cyprinids (Pisces). Monit. Zool. Ital. Suppl. 22 (1-21): 23-30.

HÜPPOP, K. 1985. The role of metabolism in the evolution of cave animals. NSS Bulletin, 47 (2): 136-146.

HÜPPOP, K. 1986. Oxygen consumption of Astyanax fasciatus (Characidae, Pisces): a comparison of epigean and hypogean populations. Environ. Biol. Fishes. 17 (4): 200-308.

JEANNEL, R. 1929. Le vivarium du jardin des plantes de l'année 1928. Revue d'Histoire Naturelle, 10: 73-92.

POULSON, T.L. 1963. Cave adaptation in amblyopsid fishes. Amer. Midl. Nat. 70: 257-290.

POULSON, T.L. 1964. Animals in aquatic environments: animal in caves. pp. 749-771. In D.B. Dill (ed.), Handbook of Physiology, IV, Amer. Phys. Soc. 47.

SINHA, K.M. and S.M. AGARWAL. 1977. A new cavernicolous orthoptera Kempiola shankari n. sp. (Orthoptera: Phalangopsidae) from Madhya Pradesh. Ind. For. 103 (2): 150-152.

VANDEL, A. 1965. Biospeleology, Pergamon Press., Oxford, London. 